\title{
THE PHYSIOLOGICAL RESPONSE TO BEE HONEY APPLICATION IN BROILER CHICKEN DIETS
}

\author{
Hamed, M.M.*; A.I. El-Faham; F. Abd El-Azeem; N.M. El-Medany; Nematallah, G.M. Ali; M.A.M. \\ Abdelaziz and A.Y.M. Abdelhady
}

Poultry Production Dept., Faculty of Agriculture, Ain Shams University, Egypt

*Corresponding author e mail: mohamed_mostafa_h93@yahoo.co

Received on:19/10/2019

Accepted on: 18/12/2019

\begin{abstract}
The aim of the present study was to investigate the effects of dietary inclusion of bee honey (BH) on broiler chicken carcass characteristics, digestive tract length, immune organs weight, villi development and blood plasma parameters. A total number of 120 one-day-old Cobb broiler chicks were randomly assigned to four dietary treatments, three replicates of 10 chicks each. A basal diet (control group) was supplemented with 3 levels of $\mathrm{BH}(0.10,0.15$ and $0.20 \%$ respectively $\left(\mathrm{T}_{1-3}\right)$. The carcass characteristics were measured, and blood plasma samples were collected for the determination of plasma concentrations of total protein, albumin, cholesterol, triglycerides, AST, ALT, calcium and phosphorus. The gastrointestinal length measurements were performed for total digestive tract and small intestine. The weights of bursa and spleen, and morphological dimensions of ileum were also measured. The results showed that there were no significant differences among dietary treatments in carcass $\%$, total edible parts $\%$, lengths of the whole digestive tract and small intestine $(\mathrm{cm} / 100 \mathrm{~g}$ body weight), spleen mass $\%$, bursa mass $\%$ or in villi width. However, broiler chickens fed the diets containing $\mathrm{BH}$ at levels of 0.15 or $0.20 \%$ exhibited slightly higher villi height than did those received the basal diet or the $0.10 \%$ BH-diet. Feeding the broiler chickens on the BH-diets slightly reduced the ileal muscle thickness compared with the control group while numbers of Goblet cells significantly increased when $\mathrm{BH}$ inclusion level reached $0.20 \%$. Data also indicated that BH addition to broiler diets had no influence on plasma levels of albumin, cholesterol, calcium and phosphorus. However, broilers fed the 0.15 or $0.20 \% \mathrm{BH}$-diets displayed significantly higher levels of plasma total protein and globulin, and lower activity of ALT as compared to other experimental groups. Activity of AST in plasma was significantly decreased in response to feeding the diets containing 0.10 or $0.15 \% \mathrm{BH}$ compared with other dietary treatments. Plasma level of triglycerides and A:G ratio were significantly lower for broilers fed the $0.10 \% \mathrm{BH}$-diet compared with other dietary treatments. In conclusion, $\mathrm{BH}$ supplementation to broiler diets had a significantly positive effects on villi development with no negative influence on chicken metabolism and immune response.
\end{abstract}

KEYWORDS: Bee honey, Carcass characteristics, Villi and Broiler chickens

\section{INTRODUCTION}

Honey is a sweet, viscous food substance produced by bees, that is produced from the sugary secretions of plants. Honey is a very concentrated water solution of two sugars, dextrose and laevulose, with small quantities of at least twenty two other more complex sugars. Many other elements also occur in honey, and the principal physical characteristics and behavior of honey are due to its sugars, but the minor constituents such as flavoring materials, pigments, acids, and minerals, are mostly responsible for differences among individual honey types (Crane, 1975).

The sugars are the foremost constituent, comprising about $95 \%$ of the honey based on dry weight, and the major sugars are the monosaccharides fructose and glucose. Additionally, about twenty five different oligosaccharides have been noticed in honey. The major oligosaccharides in honey, are the disaccharides sucrose, maltose, trehalose and turanose. In addition to carbohydrates, honey contains numerous compounds such as organic acids, proteins, amino acids, minerals, vitamins and aroma compounds (Bogdanov et al., 2003), also honey contains roughly $0.5 \%$ proteins, mainly enzymes and free amino acids. The three main honey enzymes are amylase, invertase (sucrose, $\alpha$-glucosidase), in addition to glucose oxidase (Heitkamp, 1984; Bengsch, 1992; Bogdanov and Matzke, 2003). Also, polyphenols in honey are mainly flavonoids (quercetin, luteolin, kaempferol, opigenin, chrysin, galangin), phenolic acids and phenolic acid derivatives, and all these compounds are widely known to have antioxidant properties (Gheldof and Engeseth, 2002; Kenjeric et al., 2007). Infections of the intestinal tract are common throughout the world, affecting people of all ages and pure honey has bacterial activity against many enteropathogenic organisms, including those of the Salmonella and Shigella species, and enteropathogenic E. coli (Ali et al., 1991; Jeddar et al., 1985).

Low water activity of honey inhibits bacterial growth, as honey glucose oxidase produces the antibacterial agent hydrogen peroxide (White $e t$ al., 1963), but the peroxide production capacity depends also on honey catalase activity (Dustmann, 


\section{Scientific Journal of Agricultural Sciences 1 (2): 87-93, 2019}

1991). There are also other non-peroxide antibacterial substances with different chemical origin, i.e. aromatic acids (Russell, 1988), unknown compounds with different chemical properties (Bogdanov, 1997), and phenolics and flavonoids (Cushnie and Lamb, 2005). Also, the low honey $\mathrm{pH}$ can also be responsible for the antibacterial activity of honey (Yatsunami and Echigo, 1984). In the same way, honey has been found to contain antioxidant activity including glucose oxidase, catalase, ascorbic acid, flavonoids, phenolic acids, carotenoid derivatives, organic acids, Maillard reaction products, amino acids and proteins (Beretta et al., 2005; Pérez et al., 2007). The aim of the present study was to investigate the effect of bee honey inclusion in broiler diets, on carcass characteristics, intestine morphology, some blood parameters and immune response of birds.

\section{MATERIALS AND METHODS}

The present work was carried out at poultry experimental unit, Agricultural Experiment and Research Station at Faculty of Agriculture, Ain Shams University, Egypt. A total number of 120 day-old Cobb broiler chicks were used and kept under similar managerial and environmental conditions. These chicks were housed in battery cages from one day up to 35 days of age. The chicks were randomly distributed into four equal treatment groups; each contained three equal replications. The first treatment (control) was fed the basal diets, while the other three treatments were fed the basal diets supplemented with bee honey $(\mathrm{BH})$ at levels of $0.10 \%$ (T1), $0.15 \%$ (T2) and $0.20 \%$ (T3). The three basal (starter, grower and finisher) diets were formulated on the basis of the nutrient contents of feedstuffs according to NRC (1994), and are summarized in Table 1. Birds were fed on $22.01 \%$ $\mathrm{CP}$ and $3015 \mathrm{kcal} \mathrm{ME} / \mathrm{kg}$ as a starter diet (1-14 days old), then fed on a grower diet $(20.03 \%$ CP and 3090 $\mathrm{kcal} \mathrm{ME} / \mathrm{kg}, 14-28$ days) and fed on a finisher diet (19.03\% CP and $3172 \mathrm{kcal} / \mathrm{kg}, 28-35$ days of age). At the age of 35 days, four chickens from each treatment were chosen randomly for slaughter test, individually weighed and slaughtered. For each bird, weights of blood, feathers, head and feet, viscera, abdominal fat, carcass yield and giblets (liver + gizzard + heart) were estimated and used for calculating the edible and inedible parts of carcass. Lengths of gut (total digestive tract) and small intestine were recorded as $\mathrm{cm} / 100 \mathrm{~g}$ live body weight, LBW). Immune organs (bursa and spleen) weights were recorded and calculated as percentages of LBW. Individual blood samples were collected in heparinized centrifuge tubes, then plasma was separated by centrifugation at $3000 \mathrm{rpm}$ for $15 \mathrm{~min}$. and stored at $-20^{\circ} \mathrm{C}$ in a deep freezer until further biochemical analysis.

Blood plasma parameters; levels of total protein, albumin, cholesterol, triglycerides, calcium, phosphorus, and activity of AST and ALT were colorimetrically determined using commercial diagnostic kits (Produced by Spectrum Company, Egypt). Concentration of plasma globulin was determined by subtracting the level of plasma albumin from that of total protein. Statistical analysis of data was conducted using the General Linear Model (GLM) procedure of SAS (2004). The significant differences among means of different variables were separated using Duncan's new multiple range test (Duncan, 1955) at $\mathrm{P} \leq 0.05$.

The mathematical model used was as follows: $\mathrm{Y}_{\mathrm{ij}}=$ $\mu+\mathrm{T}_{\mathrm{i}}+\mathrm{e}_{\mathrm{ij}}$

Where, $Y_{i j}=$ An observation, $\mu=$ Overall mean, $T_{i}=$ effect of treatment, $\mathrm{e}_{\mathrm{ij}}=$ random error

\section{RESULTS AND DISCUSSION}

\subsection{Carcass characteristics}

Data presented in Table 2 summarized the means of carcass characteristics (inedible and edible parts \%). All carcass traits were not significantly affected by different dietary treatments except the relative weights of abdominal fat, heart and neck. Percentages of heart and abdominal fat were significantly higher $(\mathrm{P} \leq 0.05)$ in broilers fed the $0.20 \% \mathrm{BH}$-supplemented diet than those of other dietary treatments. Relative weight of neck in birds fed the $0.15 \%$ BH-supplemented diet was significantly lower $(\mathrm{P} \leq 0.05)$ than that of other dietary treatments. The broiler chicks fed diets fortified with $\mathrm{BH}$ displayed slightly higher means of carcass yield $(66.95,67.19$ and $66.50 \%$ for $\mathrm{T} 1, \mathrm{~T} 2$ and T3, respectively) compared with the control ones. In the same manner, the fortified chicks exhibited slightly higher means of per cent abdominal fat $(1.96,1.52$ and $1.75 \%$ for $\mathrm{T} 1, \mathrm{~T} 2$ and $\mathrm{T} 3$, respectively) compared with the control ones $(1.04 \%)$.

These results partly agree with those of Oke $e t$ al. (2016), who reported that there were an increase in the percentage of carcass weight, liver, heart, gizzard and edible parts due to addition of $\mathrm{BH}$ at levels of 20, 40 and $60 \mathrm{ml} /$ liter in drinking water. Also, Obun et al. (2008) reported that the addition of $\mathrm{BH}$ in finisher broiler diets increased the percentage of abdominal fat. This result might probably due to an increase in energy production via microbial fermentation which may exceed the immediate needs of the bird to maintenance energy. However, Abioja et al. (2012) detected no significant effects of adding bee honey in drinking water on percentages of carcass yield, dressing and gizzard of broiler chickens during hot-dry season. 
Table 1. Composition and calculated chemical analysis of basal starter, grower and finisher diets.

\begin{tabular}{rccc} 
Ingredients \% & $\begin{array}{c}\text { Starter } \\
(\mathbf{1 - 1 4} \text { days })\end{array}$ & $\begin{array}{c}\text { Grower } \\
(\mathbf{1 4 - 2 8} \text { days })\end{array}$ & $\begin{array}{c}\text { Finisher } \\
(\mathbf{2 8 - 3 5} \text { days })\end{array}$ \\
Yellow Corn & 57.72 & 61.50 & 64.01 \\
Soybean meal (44\% CP) & 30.00 & 28.00 & 25.25 \\
Corn gluten meal (60\% CP) & 6.30 & 4.00 & 4.00 \\
Soybean oil & 1.80 & 2.60 & 3.20 \\
Monocalcium phosphate & 1.60 & 1.50 & 1.35 \\
Ground limestone & 1.45 & 1.35 & 1.25 \\
Lysine- HCl & 0.30 & 0.24 & 0.17 \\
DL-Methionine & 0.23 & 0.21 & 0.17 \\
Salt (NaCl) & 0.30 & 0.30 & 0.30 \\
Vit. \& min. premix & 0.30 & 0.30 & 0.30 \\
Total & 100.00 & 100.00 & 100.00 \\
\hline Calculated chemical analysis** & 3172 \\
Crude protein \% & 22.01 & 20.03 & 0.78 \\
ME (kcal/kg) & 3015 & 3090 & 0.39 \\
Calcium \% & 0.91 & 0.85 & 1.06 \\
Lysine \% & 0.45 & 0.43 & 0.50 \\
Available phosphorus \% & 1.33 & 1.19 & 0.83 \\
\hline Methionine\% & 0.61 & 0.55 & 0.89 \\
\hline
\end{tabular}

* Each $3 \mathrm{~kg}$ of premix contains: 15,000,000 IU Vit., A, 3,000,000 IU Vit. $\mathrm{D}_{3}, 50 \mathrm{~g}$. Vit. E, 3,000 mg Vit. $\mathrm{K}_{3}, 3,000 \mathrm{mg}$ Vit. $B_{1}, 8,000 \mathrm{mg}$. Vit. $B_{2}, 4,000 \mathrm{mg}$ Vit. $B_{6}, 20 \mathrm{mg}$ Vit. $B_{12}, 15,000 \mathrm{mg}$ Pantothenic acid, 60,000 mg Niacin, $1500 \mathrm{mg}$ Folic acid, $200 \mathrm{mg}$. Biotin, 200,000 mg Vit. C, $700 \mathrm{mg}$ Choline chloride, $80 \mathrm{mg} \mathrm{Mn}, 80 \mathrm{mg}$ Zinc, $60 \mathrm{mg}$ Iron, $10 \mathrm{mg}$ $\mathrm{Cu}, 1 \mathrm{mg}$ Iodine, and $0.2 \mathrm{mg} \mathrm{Se}$, where $\mathrm{CaCo}_{3}$ was used as a carrier up to $3 \mathrm{~kg}$, the inclusion rate was $3 \mathrm{~kg}$ premix/ton feed.

** Calculated analysis of the basal diets were done according to NRC (1994).

Table 2. Carcass characteristics of 35-wk-old broiler chickens fed bee honey-fortified diets.

\begin{tabular}{|c|c|c|c|c|c|c|}
\hline & \multicolumn{4}{|c|}{ Treatments } & \multirow{2}{*}{ SEM } & \multirow{2}{*}{ Sig. } \\
\hline Carcass traits: & Control & T1 & $\mathrm{T} 2$ & T3 & & \\
\hline \multicolumn{7}{|c|}{ Inedible parts (\%): } \\
\hline Blood & 3.89 & 3.25 & 3.56 & 4.06 & 0.14 & NS \\
\hline Feathers & 4.05 & 2.05 & 2.29 & 2.69 & 0.46 & NS \\
\hline Head and legs & 7.41 & 6.89 & 6.01 & 6.43 & 0.15 & NS \\
\hline Viscera & 9.75 & 10.16 & 11.12 & 9.15 & 0.11 & NS \\
\hline Abdominal fat & $1.04^{\mathrm{b}}$ & $1.96^{\mathrm{a}}$ & $1.52^{\mathrm{ab}}$ & $1.75^{\mathrm{a}}$ & 0.67 & $*$ \\
\hline Total Inedible parts & 26.17 & 24.51 & 24.09 & 24.80 & 0.64 & NS \\
\hline \multicolumn{7}{|c|}{ Edible parts (\%): } \\
\hline Carcass yield & 63.92 & 66.95 & 67.19 & 66.50 & 0.66 & NS \\
\hline Liver & 2.30 & 2.04 & 2.32 & 2.45 & 0.06 & NS \\
\hline Gizzard & 1.32 & 1.53 & 1.41 & 1.54 & 0.01 & NS \\
\hline Heart & $0.47^{\mathrm{b}}$ & $0.54^{\mathrm{ab}}$ & $0.49^{\mathrm{ab}}$ & $0.56^{\mathrm{a}}$ & 0.05 & $*$ \\
\hline Giblets\# & 4.27 & 4.12 & 4.23 & 4.57 & 0.09 & NS \\
\hline Neck & $4.85^{\mathrm{a}}$ & $4.81^{\mathrm{a}}$ & $4.07^{\mathrm{b}}$ & $4.83^{\mathrm{a}}$ & 0.64 & $*$ \\
\hline Total edible parts\#\# & 73.83 & 74.35 & 74.08 & 74.37 & 0.87 & NS \\
\hline \multicolumn{7}{|c|}{ Digestive tract length $(\mathrm{cm} / 100 \mathrm{~g} \mathrm{LBW})$ : } \\
\hline Total digestive tract & 12.66 & 13.06 & 13.90 & 12.57 & 0.35 & NS \\
\hline Small intestine & 10.51 & 10.90 & 11.05 & 10.17 & 0.21 & NS \\
\hline \multicolumn{7}{|c|}{ Immune organs weight (\%): } \\
\hline Bursa & 0.062 & 0.060 & 0.050 & 0.060 & 0.01 & $\mathrm{NS}$ \\
\hline Spleen & 0.13 & 0.13 & 0.14 & 0.15 & 0.01 & NS \\
\hline
\end{tabular}

a-b: Means in the same raw with different superscripts differ significantly (P $\leq 0.05)$. SEM: Standard error of the means. *: Significant at $\mathrm{P}<0.05$, NS.: Not significant. \#Giblets $=($ liver + gizzard + heart $)$, \#\#Total edible parts $=($ carcass yield + neck + giblets $)$. Control: No additives, T1: $0.10 \%$ Bee honey (BH), T2: $0.15 \%$ BH and T3: $0.20 \%$ BH. 


\subsection{Digestive tract length $(\mathrm{cm} / 100 \mathrm{~g} \mathrm{LBW})$}

Results presented in Table (2) showed insignificant differences among chicks fed different dietary treatments in lengths $(\mathrm{cm} / 100 \mathrm{~g} \mathrm{LBW})$ of total digestive tract and small intestine.

The means of total digestive tract length ranged between 12.57 and 13.90 in the different dietary treatments, while those of small intestine length ranged between 10.17 and $11.05 \mathrm{~cm} / 100 \mathrm{~g} \mathrm{LBW}$.

\subsection{Immune organs weight $\%$}

Results in Table 2 showed no significant effect of dietary treatments on per cent bursa of broiler chickens. In addition, chicks fed the diets supplemented with 0.15 or $0.20 \% \mathrm{BH}$ achieved insignificantly higher percentages of spleen than did other dietary treatments. These results agree with those of Osunkeye et al. (2016) and Hegazi et al. (2013), who reported that addition of BH in drinking water of broilers caused an increase in the percentages of spleen and bursa. This might be explained as BH contains flavonoids, phenols, vitamins and $\mathrm{Zn}$ which can develop the immune system of birds (Al-Mamary et al., 2002; Gheldof and Engeseth, 2002). While Abioja et al. (2012) reported that percentage of bursa and spleen of broiler chickens were not affected by addition of $\mathrm{BH}$ in drinking water at levels of 20 or $40 \mathrm{ml} / \mathrm{liter}$.

\subsection{Blood plasma parameters}

Results in Table 3 indicated that plasma total protein, globulin and $\mathrm{A} / \mathrm{G}$ ratio were significantly $(\mathrm{P} \leq 0.05)$ affected with addition of $\mathrm{BH}$ to diets of broiler chickens. The birds fed the diets supplemented with 0.15 or $0.20 \% \mathrm{BH}$ displayed significantly higher $(\mathrm{P} \leq 0.05)$ means of total protein and globulin than did other dietary treatments. These results agree with those of Oke et al. (2016), Osakwe and Igwe (2015) and Obun et al. (2008), who reported that addition of $\mathrm{BH}$ in broiler diets improved plasma concentrations of total protein, globulin and $\mathrm{A} / \mathrm{G}$ ratio, which might be attributed to improvement in digestion of crude protein and thus more availability of amino acids required for endogenous protein biosynthesis induced by oral administration with $\mathrm{BH}$. Also, the increase in globulin level with increasing dietary or drinking water levels of $\mathrm{BH}$ could be attributed to the improved immune status of birds (Gheldof and Engeseth 2002), through better efficacy of the liver to synthesize enough globulins for immunological functions. On the other hand, our results disagree with those of Osunkeye et al. (2016), who indicated that plasma total protein, albumin and globulin were not affected by dietary BH supplementation.

\subsection{Plasma cholesterol and triglycerides:}

Dietary BH supplementation to broiler chickens caused numerical decreases in plasma levels of cholesterol and triglycerides compared with that of control group (Table 3 ). These results agree with those of Oke et al.(2016) and Osakwe and Igwe (2015), who reported that the reduction in blood cholesterol and triglycerides concentrations was the most beneficial effect of $\mathrm{BH}$ on the blood lipid profile. On the other hand, our results disagree with Osunkeye et al. (2016), who indicated that BH supplementation had no effect on plasma cholesterol and triglycerides in broiler chickens.

\subsection{Plasma AST and ALT enzymes:}

Results indicated that liver function was significantly affected by treatments (Table 3). Plasma transaminases (AST and ALT) activity was significantly decreased $(\mathrm{P} \leq 0.05)$ in most treated groups with $\mathrm{BH}$ compared with the control group. This result agrees with that of Oke et al. (2016), who found a decrease in activity of plasma AST and ALT enzymes in birds fed on diets supplemented with $\mathrm{BH}$. These authors also indicated that the treatment with $\mathrm{BH}$ is beneficial and safe through modulating the liver functions. On contrary, our results disagree with the findings of Osunkeye et al. (2016), who indicated that $\mathrm{BH}$ supplementation had no effect on activity of blood plasma ALT.

\subsection{Plasma calcium and phosphorus:}

Data presented in Table 3 showed that broiler chicks fed diets supplemented with $\mathrm{BH}$ had slightly lower plasma levels of calcium and phosphorus compared with the control, with no significant differences among them. In this regard, it is known that decreased levels of plasma calcium and phosphorus might consider an indication to an enhanced utilization of calcium and phosphorus within the cells. This result agrees with that of Osakwe and Igwe (2015), who found that addition of $\mathrm{BH}$ (10 or $20 \mathrm{ml} /$ liter of drinking water) to laying hens, affected level of plasma calcium, but the level of plasma phosphorus was unaffected.

\subsection{Ileal morphology:}

Data presented in Table 4 clearly indicated broiler chickens fed the diets containing $\mathrm{BH}$ at levels of 0.15 or $0.20 \%$ exhibited slightly higher villi height than did those received the basal diet or the $0.10 \%$ BH-diet. Feeding the broiler chickens on the $\mathrm{BH}$-diets slightly reduced the ileal muscle thickness compared with the control group while numbers of Goblet cells significantly increased when $\mathrm{BH}$ inclusion level reached $0.20 \%$, but villi width was not affected. These results may refer to an improvement in intestinal morphology in birds fed the $\mathrm{BH}$-supplemented diets coincided with better health of digestive tract and its higher absorptive. The present study showed that increased villi height of the ileum, observed here, might stimulated the digestive and/or absorptive functions of broilers. 
Table 3. Blood plasma parameters of 35-wk-old broiler chickens fed BH-fortified diets.

\begin{tabular}{|c|c|c|c|c|c|c|}
\hline \multirow{2}{*}{ Items } & \multicolumn{4}{|c|}{ Treatments } & \multirow{2}{*}{ SEM } & \multirow{2}{*}{ Sig. } \\
\hline & Control & $\mathrm{T} 1$ & $\mathrm{~T} 2$ & T3 & & \\
\hline Total protein $(\mathrm{g} / \mathrm{dl})$ & $4.55^{\mathrm{b}}$ & $3.86^{\mathrm{b}}$ & $6.13^{\mathrm{a}}$ & $5.77^{\mathrm{a}}$ & 0.32 & $*$ \\
\hline Albumin (g/dl) & 1.33 & 1.25 & 1.35 & 1.63 & 0.06 & NS \\
\hline Globulin (g/dl) & $3.23^{\mathrm{b}}$ & $2.28^{\mathrm{c}}$ & $4.78^{\mathrm{a}}$ & $4.31^{\mathrm{a}}$ & 0.26 & $*$ \\
\hline AlG ratio & $0.42^{\mathrm{b}}$ & $0.75^{\mathrm{a}}$ & $0.29^{\mathrm{b}}$ & $0.40^{\mathrm{b}}$ & 0.05 & $*$ \\
\hline Cholesterol (mg/dl) & 161.66 & 159.51 & 144.41 & 125.74 & 6.74 & NS \\
\hline Triglycerides (mg/dl) & $96.38^{\mathrm{ab}}$ & $77.18^{\mathrm{c}}$ & $82.69^{\mathrm{bc}}$ & $87.64^{\mathrm{bc}}$ & 2.96 & $*$ \\
\hline AST (IU/L) & $109.82^{\mathrm{a}}$ & $77.24^{\mathrm{c}}$ & $82.00^{\mathrm{bc}}$ & $99.05^{\mathrm{ab}}$ & 0.30 & $*$ \\
\hline ALT (IU/L) & $10.56^{\mathrm{a}}$ & $9.78^{\mathrm{a}}$ & $7.50^{\mathrm{b}}$ & $6.63^{\mathrm{b}}$ & 0.44 & $*$ \\
\hline Calcium (mg/dl) & 9.87 & 9.35 & 9.10 & 8.73 & 0.30 & NS \\
\hline Phosphorus (mg/dl) & 4.65 & 4.89 & 4.71 & 4.50 & 0.10 & NS \\
\hline
\end{tabular}

a-c: Means in the same raw with different superscripts differ significantly ( $\mathrm{P} \leq 0.05)$. SEM: Standard error of the means,

*: Significant at $\mathrm{P}<0.05$, NS.: Not significant. Control: No additives, T1: $0.10 \%$ Bee honey (BH), T2: $0.15 \% \mathrm{BH}$ and T3: $0.20 \% \mathrm{BH}$.

Table 4. Effect of dietary fortification with bee honey on ileal morphology of broiler chickens

\begin{tabular}{lllllll}
\hline \multirow{2}{*}{ Ileal measurements: } & \multicolumn{2}{l}{ Treatments } & \multirow{2}{*}{ SEM } & \multirow{2}{*}{ Sig. } \\
\cline { 2 - 6 } & Control & T1 & T2 & T3 & & $*$ \\
\hline Villi height $(\mu \mathrm{m})$ & $265.94^{\mathrm{a}}$ & $235.33^{\mathrm{b}}$ & $286.67^{\mathrm{a}}$ & $290.33^{\mathrm{a}}$ & 8.21 & $*$ \\
Villi width $(\mu \mathrm{m})$ & 65.54 & 64.53 & 63.89 & 61.14 & 0.99 & NS \\
Ileal muscle thickness $(\mu \mathrm{m})$ & $108.00^{\mathrm{a}}$ & $99.85^{\mathrm{b}}$ & $103.22^{\mathrm{ab}}$ & $104.31^{\mathrm{ab}}$ & 1.23 & $*$ \\
Goblet cell numbers & $13.50^{\mathrm{b}}$ & $16.20^{\mathrm{ab}}$ & $15.86^{\mathrm{b}}$ & $17.57^{\mathrm{a}}$ & 0.54 & $*$ \\
\hline
\end{tabular}

a-b: Means in the same raw with different superscripts differ significantly $(\mathrm{P} \leq 0.05)$. SEM: Standard error of the means,

*: Significant at $\mathrm{P}<0.05$, NS.: Not significant. Control: No additives, T1: $0.10 \%$ Bee honey (BH), T2: $0.15 \%$ BH and T3: $0.20 \% \mathrm{BH}$.

Such explanation harmonizes with fact that $\mathrm{BH}$ contains a variety of substances including glucose oxidase, catalase, ascorbic acid, flavonoids, phenolic acids, carotenoid derivatives, organic acids, which are beneficial for healthy gut status (Pérez et al.2007; Beretta et al.2005).

\section{CONCLUSION}

From the obtained findings, it could be concluded that there were no adverse effects upon using $\mathrm{BH}$ in broiler diets. Also, ileal morphology measurements were considerably better in treated groups. It is also noted that the best level of $\mathrm{BH}$ supplementations in broiler chick diets was $0.20 \%$. However, future studies are needed for better understanding beneficial effects of $\mathrm{BH}$ on bird's performance.

\section{REFERENCES}

Abioja MO, Ogundimu KB, Akibo TE, Odukoya KE, Ajiboye OO, Abiona JA, Williams TJ, Oke EOand Osinowo OA (2012). Growth, mineral deposition, and physiological responses of broiler chickens offered honey in drinking water during hotdry season. I. J. Zool., Volume 2012, Article ID 403502, 6 pages.

Ali, AT, Chowdhury MN and Al-Humayyd MS (1991). Inhibitory effect of natural honey on Helicobacter pylori. Tropical Gastroenterol., 12:
139-143.

Al-Mamary M, Al-Meeri A and Al-Habori M (2002). Antioxidant activities and total phenolics of different types of honey. Nutr. Res., 22: 1041-1047.

Bengsch E (1992). Connaissance du miel. Des oligo-éléments pour la santé. Rev.Franç.apicult., 569:383-386.

Beretta G, Granata P, Ferrero M, Orioli Mand Facino RM(2005). Standardization of antioxidant properties of honey by a combination of spectrophotometric/fluorimetric assays and chemometrics. Anal. Chim. Acta, 533: 185-191.

Bogdanov S and Matzke A (2003). Honig - eine natürliche Süsse. In Matzke A, Bogdanov (ed). "Der Schweizerische Bienenvater, Bienenprodukte und Apitherapie."Winikon: Fachschriftenverlag VDRB, pp 7-40.

Bogdanov S, Bieri K, Gremaud G, Iff D, Känzig A, Seiler K, Stöckli $H$ and Zürcher $K$ (2003). Bienenprodukte; 23 A Honig. Swiss Food Manual, 1-35.

Bogdanov S (1997). Nature and origin of the antibacterial substances in honey. Lebensm. Wiss. Technol., 30: 748-753.

Crane E (1975). History of honey. In: Crane E (ed): "Honey, a comprehensive survey." London: William Heinemann, pp. 439-488.

Cushnie TPT and Lamb AJ (2005). Antimicrobial activity of flavonoids. Int. J. Antimicrob. Agents, 
26: 343-356.

Duncan DB (1955). Multiple range test and multiple F-tests. Biometrics, 11: 1-42.

Dustmann JH (1991). Über die katalaseaktivität in bienenhonig aus der tracht der heidekrautgewächse (Ericacea). Z. Lebensm. Unters. Forsch., 145:292295.

Gheldof N and Engeseth NJ (2002). Antioxidant capacity of honeys from various floral sources based on the determination of oxygen radical absorbance capacity and inhibition of in vitro lipoprotein oxidation in human serum samples. J. Agric. Food Chem., 50: 3050-3055.

Hegazi A, Abdou AM and Abdallah F (2013). Egyptian propolis 9- Its effect on chicken productivity and immune response against Newcastle disease vaccine. Br. J. Poult. Sci., 1: 2530.

Heitkamp K (1984). Pro und kontra Honig - Sind Aussagen zur Wirkung des Honigs "wissenschaftlich hinreichend gesichert"? Schriften zur Oecotrophologie 1-60.

Osakwe I and Igwe R (2015). Physiological responses of laying birds fed honey and vitamin $\mathrm{C}$ in drinking water. In: Conference on International Research on Food Security, Natural Resource Management and Rural Development. Tropentag, Sept., 16-18, Berlin, Germany.

Jeddar A, Kharsany A, Ramsaroop UG, Bhamjee $A$, Haffejee IE and Moosa A (1985). The antibacterial action of honey.Anin vitro study. S. Afr. Med. J., 67:257-258.

Kenjeric D, Mandic ML, Primorac L, Bubalo D and Perl A (2007). Flavonoid profile of Robinia honeys produced in Croatia. Food Chem., 102: 683690.

National Research Council, NRC (1994).. Nutrient
Requirements of Poultry, $9^{\text {th }}$ Edition. National Academy Press, Washington, D.C. USA.

Obun CO, Yahaya MS, Olafadehan OA, Kehinde AS, Allison DS, Yusuf AM and Farouk U(2008). Dietary value of honey and its effects on abdominal fat deposit, blood and serum profile of finisher broiler chicks. J. Agric. Forestry Soc. Sci., 6: 173-181.

Oke OE, Sorungbe FO, Abioja MO, Oyetunji O and Onabajo AO (2016). Effect of different levels of honey on physiological, growth and carcass traits of broiler chickens during dry season. Acta Argiculturae Slovenica, 108: 45-53.

Osunkeye OJ, Fakolade PO, Alabi BO, Akinduro VO and Olorede BE (2016). Physiological, serum and haematological responses of broiler fed honey at varying levels of inclusion in the diet. J. Nat. Sci. Res., 6: 71-75.

Pérez RA, Iglesias MT, Pueyo E, Gonzalez M and de Lorenzo C (2007). Amino acid composition and antioxidant capacity of Spanish honeys. J. Agric. Food Chem., 55: 360-365.

Russell KM, Molan PC, Wilkins AL and Holland PT (1990). Identification of some antibacterial constituents of New Zealand manuka honey. J. Agric. Food Chem., 38:10-13.

SAS (2004). Statistical Analysis System, SAS User's Guide: SAS Institute Inc., Cary, NC. USA.

White JW, Subers MH and Schepartz AI (1963). The identification of inhibine, the antibacterial factor in honey, as hydrogen peroxide and its origin in a honey glucose-oxidase system. Biochim. Biophys. Acta., 73: 57-70.

Yatsunami K and Echigo T (1984). Antibacterial action of honey and royal jelly. Honeybee Sci., 5: $125-130$ 


\section{الملخص العربي \\ الإستجابة الفسيولوجية لبدارى التسمين لإضافة عسل النحل في العلائق}

محمد مصطفى حامد، أحمد إبرا هيم سليمان الفحام، فتحي عبد العظيم محمد، نبيل محمد حسن المدني، نعمة الله جمال الدين محمد على، الدئ



قسم إنتاج الدو اجن- كلية الزر اعة- جامعة عين شمس- القاهرة- مصر

تهدف هذه الدراسة إلى تقييم تأثير إضافة عسل النحل إلى علائق بدارى التسمين على صفات الذبيحة وطول القناة الهضمية ووزن



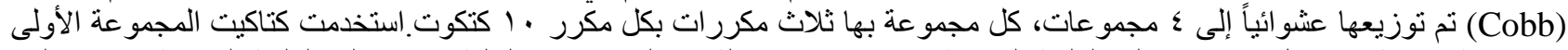

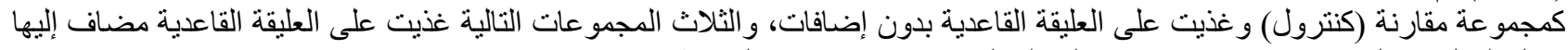

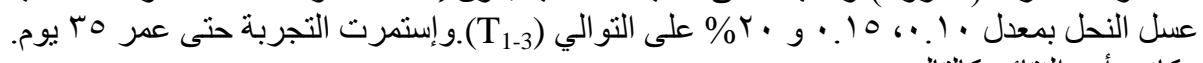



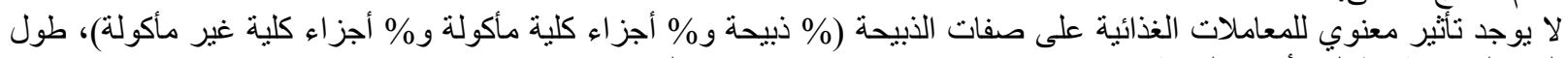

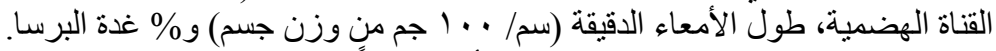





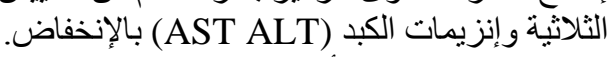

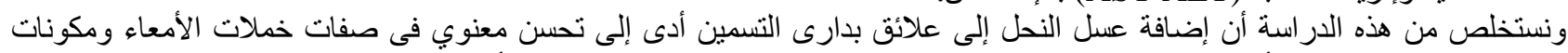

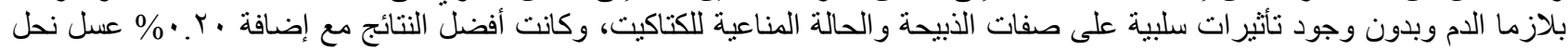
إلى علائق بدارى التسمين. 